\title{
IMPORTANCE OF FEEDBACK INFORMATION FROM FARM ACCOUNTANCY DATA NETWORK OF THE REPUBLIC OF SERBIA ${ }^{1}$
}

\author{
Vlado Kovačevič², Mirjana Bojčevski ${ }^{3}$, Biljana Chroneos Krasavac ${ }^{4}$
}

\begin{abstract}
The objective of this paper is the analysis of the feedback information from the Farm accountancy data network (FADN) in the Serbia.

The objective of FADN is to ensure the compulsory annual reports to the European Commission, as well as for the analytics and development of a national agro-sector. The significance for the national agro-sector is primarily by providing feedback information to domestic farmers.

Analyses in this paper were determined the need and possibility for inclusion in FADN feedback form indicators of gross margin for every production line, which can be calculated from already existing data. The importance of gross margin as an indicator of profitability is significant from the perspective of farmers.
\end{abstract}

Key words: FADN, feedback information, agricultural household, agricultural policy, farm income.

JEL: $Q 12, Q 18$

\section{Introduction}

Farm Accountancy Data Network (FADN) is based on the collecting annually production, economic and financial data from a sample of farms, classified into groups according to

1 This paper is a result of the project III - 46006: Sustainable agriculture and rural development in terms of the Republic of Serbia strategic goals realization within the Danube Region, financed by the Ministry of Education, Science and Technological Development of the Republic of Serbia.

2 Vlado Kovačević Ph.D., Assistant Researcher, Institute Agricultural Economics, Volgina Street no. 15, 11000 Belgrade, Serbia, Phone: +381 6465815 19, E-mail: vlado.kovacevic@minpolj.gov.rs

3 Mirjana Bojčevski M.A., Senior Adviser, Ministry of Agriculture and Enviromental Protection, Nemanjina Street no. 22-26, 11000 Belgrade, Serbia, Phone: +381 6433020 05, E-mail: mirjana. bojcevski@minpolj.gov.rs

4 Biljana Chroneos Krasavac Ph.D., Assistant Professor, University of Belgrade, Faculty of Economics, Kamenička Street no. 6, 11000 Belgrade, Serbia, Phone: +381 113021186 , E-mail: biljanak@ekof.bg.ac.rs

EP 2017 (64) 3 (1147-1159) 
the criteria of economic farm size, type, or the type of agricultural production and regional affiliation (Ranogajec et al., 2014).

The Farm Accountancy Data Network (FADN or EU - FADN) is an instrument, launched in 1965., for evaluating the incomes and business operation of agricultural holdings and the impacts of the Common Agricultural Policy (CAP) viewed from the EU level. To do this it uses data contributed by national farm accounts surveys in each Member State in the form of completed "Farm Returns". Member States receive a standard fee from the Commission for each duly completed "Farm Return", within certain rules established by the FADN legislation. The current legal base is Council Regulation (EC) No 1217/2009 (Bradley, Hill, 2015).

The prevailing held view is that accounting information can improve farm management (financial leverage, forecasting, farm viability), providing that the employed accounting reports are consistent with agro-economic data and sustainable-logic plans, are also consonant with CAP and Ministry's Agriculture Policy. So the option of uniform approach with harmonized statistics in Agriculture sector, seem to be prime principle for the farm community (Vazakidis et al., 2010).

FADN provides detailed financial economic information at farm level on more than 80,000 farms in Europe. The data are collected in a systematic way on an annual basis and the information collected for each sample farm contains more than 1,000 variables. FADN contains harmonised farm-level data across Europe: the data elements to be provided to the European Commission (EC) and bookkeeping principles (such as depreciation) are the same in all countries (Vrolijk et al., 2016). Within its field of observation, FADN provides data which are representative in terms of region, economic size and type of farming and which also cover the vast majority of agricultural production (Bradley, Hill, 2016).

Derived from national surveys, the FADN is the only source of microeconomic data that is harmonized, i.e. the bookkeeping principles are the same in all countries. Holdings are selected to take part in the survey on the basis of sampling plans established at the level of each region in the Union. The survey is based on sample farms participating in FADN survey, only those which due to their size are considered commercial. The applied methodology aims to provide representative data along three dimensions: region, economic size and type of farming (Pitulice, Gorgan, 2013). While the European Commission is the primary user of analyses based on FADN data, the aggregated data can be found in the Standard Results database (Regulation (EC) No 1166/2008). The aim of the network is to gather accountancy data from farms for the determination of incomes and business analysis of agricultural holdings (Marongiu et al., 2012). FADN sample represent a population of about 5,000,000 farms in the EU, which covers approximately $90 \%$ of the total utilized agricultural area (UAA) and account for about $90 \%$ of the total agricultural production (Vasiljevic et al., 2016).

FADN data are of great significance for different types of users, including institutions such as: creators of agricultural and rural policy (Ministry and the Provincial Secretariat), regional authorities, educational and science-research institutions, agricultural extension and professional services and farmers. 
The success of the FADN research depends a lot on the motivation of farmers who are involved in sample. If this neglects, farmers will consider the FADN research as an unnecessary extra work, since they don't keep the financial record on agricultural activities.

Primary motive of farmer is to ensure successful farm business, i.e. to realize the economy (make higher total income with fewer costs), profitability (make more profit with less assets employed) and productivity (manufacture a certain amount of products with less labour expenditure).

Providing feedback information to farmers is not obliged in the FADN research. It means that there is no requested from the European Union to provide and analyse any feedback information to the farmers. However, it is considered as an integral part of good practice of FADN research that the feedback information is provided and analysed to the farmers.

FADN in Serbia has started in 2012, with increasing number of agricultural holdings in sample. The sample in the 2016. comprised 1,200 holdings, while a necessary number of holdings for the full representativeness are around 2,000.

The Republic of Serbia has chosen to collect FADN data via the agricultural advisory services. The FADN system in Serbia anticipates that extension officers visit farmers four times per year:

- In January/February, in order to start collecting data for a new year (at this meeting, the accounting reports for the previous year conclude and open new accounting reports for the following year);

- In April, to keep track of data record for the first quarter;

- In July, to keep track of data record for the second quarter and provide feedback information on business of an agricultural holding in the previous year, as well as advices for the improvement of agricultural holding business in future;

- In October, to keep track of data record for the third quarter and preparations for the next year.

Feedback information on farm business provides indicators of productivity and competitiveness. There are numerous benefits for farmers from the FADN feedback information, and the most important among them are:

- Better review and monitoring of business at the level of entire holding;

- Better planning through regular book keeping practice;

- Comparing the production results with the results of other farms in the region, and also comparing the results with other producers who are engaged in the same type of production;

- Finding more efficient models of production and establishing business contacts with other farmers, due to comparison, but also the improvement in the field of trading with some agricultural products/materials; 
- Contact with data collectors (consultants), who will provide useful information and advices, not only related to the FADN system;

- Facilitated application for public structural funds (state funds, IPARD, etc.).

\section{Methodology and data sources}

This paper continues the research regarding the FADN development, role and the impact of feedback information.

Aim of this paper is to determine importance of FADN feedback information for farmers, FADN system development and policy makers. Second aim is to recommend based on analysis results steps toward improvement of FADN feedback form in Serbia.

Methodology used in this paper:

- Desk research method;

- Literature review;

- Interview with relevant experts,

- Method of analysis and synthesis.

The paper is based on different data sources. The first group includes three types of documents, i.e. academic papers, all legal acts covering this field in Serbia from the beginning of coop movement and finally, official documents and reports of EU and the other international organizations. The second sources are the empirical data. The empirical data were collected through structural interviews of key stakeholders involved in FADN Serbia. There were several sessions involving researchers in discussion process based on the list of questions prepared in advance, targeted to the main FADN feedback information form. The content of the answers and responses collected through this process were analysed in order to extract the key factors that shaped the development of FADN feedback information. Who was interviewed?:

- Farmers;

- Creators of agrarian policy - Ministry of Agriculture and Environmental Protection of the Republic of Serbia;

- Professional public - scientific institutions engaged in the scientific fields of agriculture and agrarian economy.

Third source of information was Serbia FADN database and EU FADN database, where all existing data, which were collected in the FADN system, were analysed. The possibility of their use for the purpose of obtaining new useful indicators was analysed as well. The special significance for FADN in Serbia is the development of FADN feedback information, based on already existing data, since FADN system in Serbia has developing, and additional inclusion of new data in collecting requirements for additional changes of forms, FADN software and training of agricultural consultants, which would place a strain on the system in the development phase. 


\section{Results and discussion}

The role and significance of feedback information of FADN system for farmers in Serbia are analysed in this paper. The FADN feedback information serves as a „diagnostic" tool for farmers, in order to assess where a farm currently is and in which fields of business has better/ worse results in regard to an average of all farmers in the same production line. For example, an agricultural holding can conclude based on FADN feedback form that it buys inputs $10 \%$ more expensive than the average, which is the signal to pay attention to lowering of input prices, etc.

Dissemination of data can be at the level of: EU, national level and locally, at the farm.

Dissemination of data at the EU level is regular distribution of FADN data based on the standard results that generate according to validated summary FADN forms of accounting data for agricultural holdings, checked by the European Commission (FADN, 2016). Standard results are the set of statistical data, calculated in accordance to forms of agricultural holdings accounting data, which the European Commission periodically prepares and publishes. They are available in public database and describe in detail the economic situation of farmers by different groups the European Union-wide (Bojcevski et al., 2016).

Annual reports and statistical data on economic-financial situation in agricultural sector and analyses on user's request create at the national level. These reports can be useful for farmers who are not involved in FADN sample and who can compare their holding's business results with the average of groups in the same line production. In order to create benchmarks for individual agricultural holdings, as well as more specific analyses for the needs of ministry and the agricultural extension service, there should be possible to provide the statistical data for agricultural holdings with more detailed/specific definition of production type. Such statistical data should respect the confidentiality of data, and show results only if there are at least five agricultural holdings in the group (Bojcevski et al., 2015).

Dissemination at the local level implies the creation of feedback information for farmers as an additional motivation to take part in the FADN system. The feedback information is an integral part of implementing the FADN research in the Republic of Serbia, because ones assessed that farmers need the additional motivation for keeping in detail record, and in many case, they kept this record only due to a special relation with a consultant. Analyses and tracking of all activities within the FADN research help farmers in making higher profits. These data provide information necessary for making right business decisions, such as determination of business results in a holding, determination of ownership rights, providing data for the control of planned activities and analyses of all activities aiming to improve business (Vasiljevic et al., 2012).

The FADN feedback form, provides to the farmers involved in the FADN research, is of special importance for the Republic of Serbia, since farmers who take part in FADN do not get any additional financial compensations. The only benefit they receive from being a part of FADN research is primarily in the feedback form and possibility to analyse their business and improve it based on this feedback form.

Furthermore, farmers from agricultural extension officers, who collect FADN data in 
holdings, are well trained and obliged to help farmers in interpretation and analysis of feedback information.

Presenting the business results of an agricultural holding (overview of feedback information for farmers) requires the presentation of the group of business result indicators. Indicators, which will be included in the feedback information (integral part of FADN database), defines a working group of participants in the FADN system, according to experience and requirement of consultants and farmers.

The feedback form for farmers ensures the multi-level review of business results of an agricultural holding:

- General indicators;

- Yield;

- Balance sheet;

- Financial indicators;

- Additional indicators.

General indicators show data for invested labour expressed in annual working units (AWU), total utilized agricultural area in ha, and average number of heads of cattle.

Yields can be expressed for the most significant crops and permanent cropping, and also milking capacity per cow during the year.

Balance sheet at the end of the year shows total working capital and fixed assets, total liabilities (long-term and short-term credits) and capital net value at the end of the year. The FADN-system is the most detailed and best possible statistics for studying the level of farm income and its development in different EU-countries (Poppe, 2004).

Financial indicators shown through total production value, total specific costs, total overhead costs of agricultural holding, total subsidies and taxes (excluding tax on investments), and gross income of agricultural holding. The feedback information shows amortization, net added value of agricultural holding, total external factors and net income of a holding (legal entity) (or income of family agricultural holding, if it is about the individual agricultural holdings). Net income is expressed by hectare, without subsidies per hectare and per working hour of unpaid labour (Bogicevic et al., 2016).

Additional indicators are shown through gross investments in fixed assets per ha of used agricultural land, debt-equity ratio, coefficient of economy and ratio of current assets to current liabilities. Very important indicators for producers, which get in the feedback information, are gross margin of plant production and products, gross margin of livestock production and products, and gross margin of other activities, products and services.

All indicators derived from FADN feedback form can be in function of economic prosperity of household (Diazabakana et al., 2014).

At the Scheme 1. is presented rational for calculation of main financial indicators. 
Scheme 1. Calculation scheme of the main financial indictors

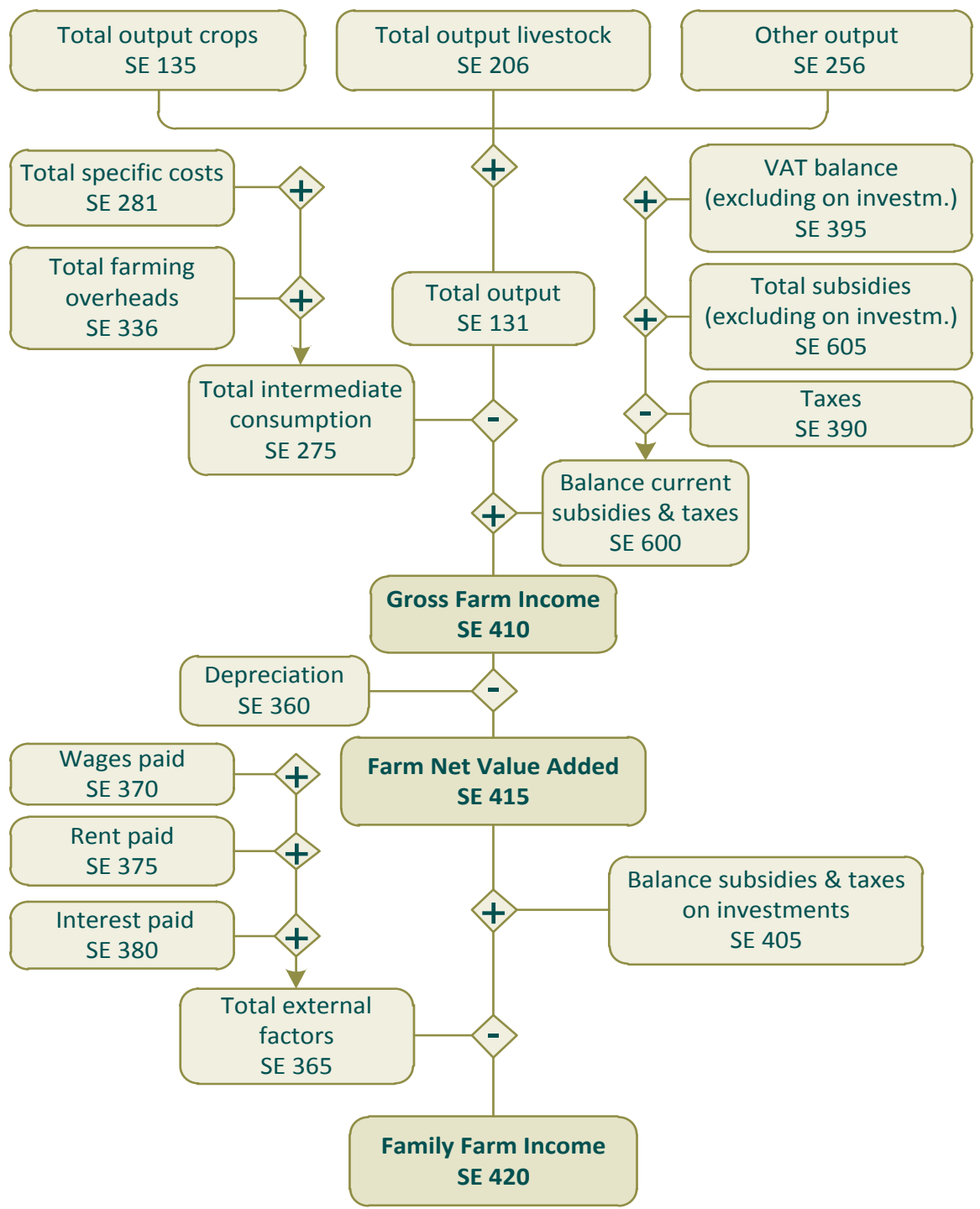

Source: FADN Serbia, 2016.

Data presented in the feedback information are the review of business results of an agricultural holding and each data can be compare against average values for a comparable group of farms (Bojcevski et al., 2015).

Indicators for the comparable group can be calculated according to a small number of agricultural holdings, which participate in the FADN system, with the same production type, regardless to size and other indicators. For that reason, there may be significant differences in regard to data from individual holdings. If number of holdings is small and not representative for the specific group of agricultural holdings, the presented data cannot be used for economic 
analyses or a status evaluation of agricultural sector in whole. It is necessary to verify in a statement that data from individual agricultural holdings are confidential and won't be used for tax purposes, but they are meant only for the purpose of FADN system of the Republic of Serbia.

The provided feedback information for an agricultural holding should be summarized on three pages, with clearly defined significant indicators, comparative results of an agricultural holding and average group for the same production line, as well as charts which show concretely the obtained results.

Farmers, who are engaged in FADN sample, receiving the feedback information. Extension officer help them in interpreting the obtained results.

Farmers, who are not engaged in FADN sample, can use FADN reports directly, with exception that they make by their own the business results of their holdings, based on which compare with the average result for the same production line.

At the Figure 1. is presented one of the potential uses of FADN indicators (calculation of structure of total output, including subsidies, excluding on investments which can be uses in analytical purpose).

Figure 1. Structure of total output (including subsidies, excluding on investments)
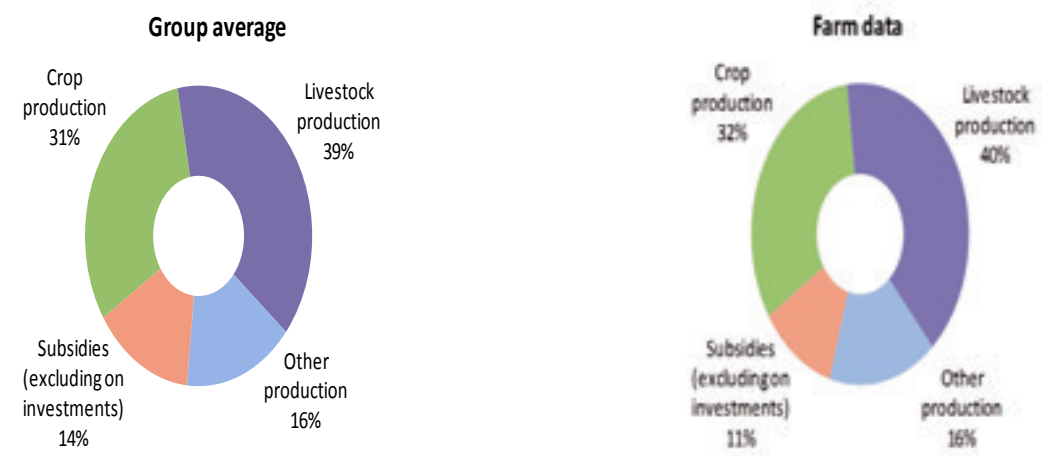

Source: FADN Serbia, 2016.

The FADN system in Serbia requires signing a Statement on Data ${ }^{5}$ when creating the feedback information, which implies mutual responsibility of the system participants. It means that the obtained results and data used in this analysis are collected at agricultural holdings by the FADN methodology, and they base on information obtained from farmers. They can base on systematically kept record and/or evaluation of a farmer. The results, obtained based on the accounting register, ensure better assessment of economic position of agricultural holding. Presented data in the feedback information represent the evaluation of business results of an agricultural holding, as well as the average values for the comparative group of agricultural

5 Statement of a holder/manager of agricultural holding and a person responsible for collecting data on the obtained business results of agricultural holding. 
holdings which take part in the FADN system for the current year6.

FADN feedback can serve to Serbian farmers to compare their business with other EU colleagues' businesses.

Analysis of a FADN questionnaire with data that already were collected, as well as the analysis of farmers' and the agrarian policy creators' needs led to the conclusion that the inclusion of gross margin indicators would be of great significance for FADN feedback information in Serbia.

Financial indicator, gross margin, is very important for farmers, who strive to make as higher as possible total gross margin, i.e. that the proportion of production lines with the highest gross margin would be higher in its production structure (Vuckovic, 2016). From the aspect of agricultural households, development of calculations based on gross margin is simple, transparent and easy to apply model for the analysis of sustainability of adopted production technology and achieved production results (Subić et al., 2015).

For the agrarian policy creator, this indicator is significant, while it shows profitability of individual lines of agricultural production. Gross margin indicator uses for many years for measuring the efficiency of an extension professional service, so the mentioned indicator within FADN could serve the same purpose at the regional and republic level.

The equation is as follows: PROFIT = GROSS MARGIN - FIXED COSTS

When creating the gross margin indicators, it is necessary to allocate general expenses, which are not related just to one production line, to every line of production present in a holding ${ }^{7}$. Using this approach and already existing data and distribution of general costs doesn't require any changes in the current way of collecting data (Milojević, 2017), but all calculations are made on existing data, which is advantageous, especially in the initial phases of the FADN system development, when the system is ahead of numerous obligations.

This procedure of costs allocation to part which charges a household and part which charges a holding, as a production unit, doesn't appear exclusively within the general expenses group, but also in other places.

The following costs count among the general expenses by the FADN methodology (EC, 2015):

- Current maintenance of soil meliorations and maintenance of soil meliorations and facilities;

- Costs of electrical energy, heating fuel, water;

- Insurance costs, taxes and contribution costs;

6 Comparative analyses of the specific groups of agricultural holdings are not possible to calculate, due to a small number.

7 This approach has its imperfections in possible deviations in costs allocation ,according to the key "in regard to real costs allocation.

EP 2017 (64) 3 (1147-1159) 
- Rent costs;

- Costs of interests and other financial compensations (reimbursement);

- Other general expenses (such as the costs of accounting services, office supplies, phone costs, subscription fees, etc.).

Introduction of the gross margin indicators would contribute to FADN improvement in Serbia, through the analysis of production line profitability at farm level.

Based on the conducted analyses, recommendation can be drawn to enter into FADN software a direct calculation of gross margin in coming years, by direct monitoring of costs related to individual production lines. This will increase a size and complexity of collecting data, but also will increase the accuracy of calculating the gross margin. The general expenses wouldn't allocate ,according to the key“, but according to costs which were directly fixed by the questionnaire.

\section{Conclusion}

Every member-country is obliged to collect and submit data to the EU Commission within the FADN system, but besides, every country has at its disposal the upgrade of the FADN system and using the additional reports for national needs. Creation and distribution of the FADN feedback information is not regulated by the general EU regulatory rules, so every country can adjust this segment to their own needs.

It is very important for countries which don't pay financial compensation to producers involved in the FADN sample, to provide the FADN feedback information in high-quality, since the feedback information and possibility for business improvement of a holding, based on the feedback information, is a basic motive for farmers to be included in the FADN sample in Serbia. Therefore, the development of FADN feedback information has a greater significance for functioning of FADN system in relation to some other EU countries.

According to the FADN feedback information, farmers could analyse farm business, comparing some business segments with the group average of producers in the same production line.

Within the research was concluded that there is the possibility to introduce the financial indicator - gross margin in the FADN feedback form. This indicator is very important for farmers, who strive to make as higher as possible total gross margin, i.e. proportion of production lines with the highest gross margin would be higher in its production structure. For the agrarian policy creator, this indicator is significant, while it shows profitability of individual lines of agricultural production. Gross margin indicator uses for many years for measuring the efficiency of an extension professional service, so the mentioned indicator within FADN could serve the same purpose at the regional and republic level.

Besides the development of indicators in a feedback form, the accuracy of collected data is necessary for the high-quality feedback information and other FADN reports. Daily record keeping is crucial, and it will be only possible if farmers are properly motivated for carrying 
out the FADN research, as a direct advantage in managing an agricultural holding (farm management).

FADN workshops should be planned at least once a year for all farmers, who are involved in the FADN research. The best time for these meetings is at the end of winter, or period from January to mid-March, when farmers have the least farm (field) work. It is good to mix these meetings with the presentation of subsidies by the ministry, since farmers will get an impression that they get additional advantages in regard to other producers who don't take part in the FADN research. It is important to emphasize at these meetings that the confidentiality of collected data will be protected and not used for tax purposes. Farmers must get some kind of a certificate from the FADN system, because many of them are still afraid of taxation and therefore give inaccurate data. There has to be explained that the data analysis will be possible only at the overall level of at least five farmers, the rules on data confidentiality will be clear and strict and data will be used only for the purposes of the FADN research (in accordance with the European Union regulation related to FADN).

The recommendation is to introduce the direct research of general expenses of individual production lines due to the FADN feedback information significance in Serbia in coming years, by which the suggested existing methodology of gross margin calculation through the general expenses allocation to individual production lines, by using ,the key“ for allocation, would be replaced with more precise direct allocation.

It is inevitable to research and improve the FADN system in Serbia continuously through the development of national indicators, which will be useful for the national agro-sector.

\section{References}

1. Bogicevic, J., Domanovic, V., Krstic, B. (2016): The role of financial and non-financial performance indicators in enterprise sustainability evaluation, Ekonomika, Vol. 62, No. 3, pp. 69-79.

2. Bojcevski, M., Kovacevic, V., Subic, J. (2015): Importance of a farm accountancy data networks (FADN) for agricultural sector in Serbia, Proceedings of abstracts, $2^{\text {nd }}$ international symposium for agriculture and food ISAF 2015, Faculty of Agricultural Sciences and Food, Skopje, October 2015, Ohrid, Republic of Macedonia, p. 48

3. Bojcevski, M., Kovacevic, V., Subic, J. (2016): Roll of a farm accountancy data networks (FADN) in agricultural sector in Serbia, Ekonomika, vol. 62, no. 3, pp. 69-79.

4. Bradley, D., Hill, B. (2015): Cost of and good practices for FADN data collection, report no. EUR 2015.4546 EN, European Commission, Directorate-General for Agriculture and Rural Development, Brussels, Belgium, p. 179, available at: www.ceasc.com/Images/ Content/Cost $\% 20$ of $\% 20$ and $\% 20$ good $\% 20$ practice $\% 20$ in $\% 20$ FADN\%20data $\% 20$ collection-\%20Final\%20report.pdf

5. Bradley, D., Hill, B. (2016): Comparative analysis of the FADN data collection systems in EU-28, Proceedings, 90 ${ }^{\text {th }}$ Annual Conference of the Agricultural Economics Society, University of Warwick, Coventry, England, April 2016, pp. 1-18, available at: http:// 
ageconsearch.umn.edu/bitstream/236324/2/Berkeley_Hill_Hill_Bradley_AES2016 FINAL.pdf

6. Diazabakana, A., Latruffe, L., Bockstaller, C., Desjeux, Y., Finn, J., Kelly, E., Ryan, M., Uthes, S. (2014): A review of farm level indicators of sustainability with a focus on CAP and FADN, FLINT Project results, University of Wageningen, the Netherlands, p. 101, available at: http://www.flint-fp7.eu/downloads/reports/FLINT\%20WP1\%20_D1_2.pdf

7. EC (2015): Commission Implementing Regulation (EU) 2015/220 of 3 February 2015 laying down rules for the application of Council Regulation (EC) No 1217/2009 setting up a network for the collection of accountancy data on the incomes and business operation of agricultural holdings in the European Union, European Commission, Brussels, Belgium, available at: http://publications.europa.eu/en/publication-detail//publication/8c2f2ba4b80b-11e4-b3fe-01aa75ed71a1/language-en

8. FADN (2016): FADN agriculture overview, EU Commission web portal, Brussels, Belgium, available at: http://ec.europa.eu/agriculture/rica/, accessed on: February 2016.

9. FADN Serbia (2016): Farm return 2015, Ministry of Agriculture and Environmental protection of the Republic of Serbia, Belgrade, available at: http://www.fadn.rs/web/wpcontent/uploads/2016/08/FADN-Serbia_Farm_Return2015.pdf, accessed: December 2016.

10. Marongiu, S., Cesaro, L., Florian, D., Tarasconi, L. (2012): The use of FADN accounting system to measure the profitability of forestry sector, Italian Journal of Forest and Mountain Environments, Vol. 67, No. 3, pp. 253-261.

11. Milojević, I. (2017): Računovodstveni informacioni sistem i informacije u sistemu odbrane, Oditor, Vol. 3, No. 2, pp. 54-66.

12.Pitulice, I. C., Gorgan, C., (2013): The use of statistical information for financial reporting purposes - the case of FADN, Annales Universitatis Apulensis Series Oeconomica, Vol. 15 , No. 1 , pp. 67-80.

13. Poppe, K. J. (2004): Income issues in farm households and the role of the FADN, Report no. 8.04.03, Pacioli 12, Agricultural Economics Research Institute (LEI), Hague, the Netherland, p. 99, available at: http://library.wur.nl/WebQuery/wurpubs/fulltext/89881

14. Ranogajec, L., Deže, J., Tolić, S. (2014): FADN as an indicator of the success of agricultural production, Journal of Hygienic Engineering and Design, Vol. 9, pp. 80-84.

15. Subić, J., Jeločnik, M., Zubović, J. (2015): Primena navodnjavanja kao agrotehničke mere - analiza marže pokrića u proizvodnji kukuruza, Ecologica, Vol. 22, No. 78, pp. 245-251.

16. Vasiljevic, Z., Kovacevic, V., Stankovic, S. (2016): Farm accountancy data network as a tool for measuring efficiency of applied new technologies in agriculture, Thematic proceedings, $152^{\text {nd }}$ EAAE Seminar, SAAE, Belgrade, September 2016, Novi Sad, Serbia, pp. 138-152.

17. Vasiljevic, Z., Zaric, V., Ivkov, I. (2012): Recording of accountancy data at the family farms in Serbia, Thematic proceedings, $3^{\text {rd }}$ International Scientific Symposium Agrosym - Jahorina 2012, Faculty of Agriculture, Srpsko Sarajevo, Jahorina, BiH, November 2012, pp. 599-604. 
18. Vazakidis, A., Stergios, A., Laskaridou, E. (2010): The Importance of information through accounting practice in agricultural sector-European data network, Journal of Social Sciences, Vol. 6, No. 2, pp. 221-228.../../Toshiba/Downloads/SSRN-id1829426.pdf

19. Vrolijk, H., Poppe, K., Keszthelyi, S. (2016): Collecting sustainability data in different organisational settings of the European farm accountancy data network, Studies in Agricultural Economics, Vol. 118, pp.138-144.

20. Vuckovic, B. (2016): Causes of different profitability of agricultural sector, Economics of Agriculture, Vol. 63, No. 1, pp. 123-143.

\title{
ZNAČAJ POVRATNE INFORMACIJE SISTEMA RAČUNOVODSTVENIH PODATAKA NA POLJOPRIVREDNIM GAZDINSTVIMA REPUBLIKE SRBIJE
}

\author{
Vlado Kovačevič ${ }^{8}$, Mirjana Bojčevski ${ }^{9}$, Biljana Chroneos Krasavac ${ }^{10}$
}

\section{Sažetak}

Cilj radaje analiza značaja i davanje preporuka za unapređenje povratne informacije Sistema računovodstvenih podataka na poljoprivrednim gazdinstvima (FADN) Republike Srbije.

Svrha FADN-a je obezbeđenje godišnjih obaveznih izveštaja prema Evropskoj Komisiji, kao i upotreba u svrhu analitike irazvoja nacionalnog agrosektora. Značaj za nacionalni agrosektor je pre svega u delu obezbeđenja povratne informacije domaćim poljoprivrednicima kojima ovakvi izveštaji omogućavaju da uporede rezultate svoga poslovanja sa rezultatima grupnog proseka za istu liniju proizvodnje.

Analizom u okviru rada utvrdila se potreba i mogućnost uključivanja u FADN formular sa povratnom informacijom, indikatora bruto marže za svaku liniju proizvodnje. Bruto marža se može izračunati iz već postojećih podataka u okviru FADN-a. Značaj bruto marže kao pokazatelja profitabilnostije velika iz ugla poljoprivrednika koji se na osnovu ovog pokazatelja mogu odlučiti za profitabilniju liniju proizvodnje i pratiti profitabilnost svoje proizvodnje.

Ključne reči: FADN, povratna informacija, poljoprivredno gazdinstvo, agrarna politika, prihod poljoprivrednog gazdinstva.

8 Dr Vlado Kovačević, Naučni saradnik, Institt za ekonomiku poljoprivrede, Volgina ulica br. 15, 11000 Beograd, Srbija, Telefon: +381 6465815 19, E-mail: vlado.kovacevic@minpolj.gov.rs

9 Mr Mirjana Bojčevski, Viši savetnik, Ministarstvo poljoprivrede i zaštite životne sredine Republike Srbije, Nemanjina ulica br. 22-26, 11000 Beograd, Srbija, Telefon: +381 6433020 05, E-mail: mirjana.bojcevski@minpolj.gov.rs

10 Vanredni profesor, dr Biljana Chroneos Krasavac, Univerzitet u Beogradu, Ekonomski fakultet, Kamenička ulica br. 6, 11000 Beograd, Srbija, Telefon: +381 1130211 86, E-mail: biljanak@ekof.bg.ac.rs

EP 2017 (64) 3 (1147-1159) 